\title{
EFFECT OF POLYCHLORINATED BIPHENYLS (PCB) ON THE INFECTION OF CHICKENS WITH TURKEY HERPESVIRUS THV-BIO-I
}

\author{
R. HALOUZKA ${ }^{1}$ and V. JURAJDA ${ }^{2}$
}

Department of Pathomorphology${ }^{1}$, Clinic of Avian Diseases, University of Veterinary Science, 61242 Brno

Received October 22, 1991

\begin{abstract}
Halouzka, R. and V. Jurajda: Effect of Polychlorinated Biphenyls (PCB) on the Infection of Chickens with Turkey Herpesvirus THV-BIO-I. Acta vet. Brno, 61, 1992: 133-139.

The effects of polychlorinated biphenyls (Delor 103) on Brown Hisex chickens infected with vaccination turkey herpesvirus THV-BIO-I were studied in a 5-week experiment. One group of 1-day-old chicks were infected in doses of approximately $10^{3}$ PFU per bird and fed a commercial feed mixture K. Another group of chicks were infected in the same way and fed feed mixture $\mathrm{K}$ contaminated with PCB (Delor 103) at $50 \mathrm{mg} \mathrm{.} \mathrm{kg-1}$ feed mixture. Non-infected chickens fed non-contaminated feed mixture $\mathrm{K}$ were used as controls. At weekly intervals the chickens were subiected to serological examination and weighed, and their lymphoid organs, skin, nerves and gonads were examined histopathologically.

PCB (Delor 103) produced a reduction in body mass and a disturbance in feather growth. The incidence of lymphoid cellulisates in the organs was not affected. The lymphoid organs of chickens merely infected with THV-BIO-I exhibited only moderate cytolytic changes; atrophy of the spleen and of the bursa of Fabricius were found at the end of the experiment. The lymphoid organs of chickens both infected and fed PCB (Delor 103) showed more conspicuous regressive changes from the 3rd week p. i. These may be a cause of vaccination failure. Post-infection antibody was not found in any of the birds. Brown Hisex chickens were apparently more resistant to the effects of PCB (Delor 103) than Brown Leghorn chickens used in a previous experiment.
\end{abstract}

Brown Hisex chicken, PCB, Turkey herpesvirus THV-BIO-I, lymphoid organs, immunosuppression

The causes of inadequate protection of poultry after vaccination are related in general to potency of the vaccine and to host and ecological factors. Included among these factors can be the presence of maternal antibody, genetic make-up, incidence of infectious agents of various pathogenicity and immunosuppression of all sorts of origin. In our previous experiments on chickens polychlorinated biphenyls (Delor 103) were found to exert a strong immunosuppressive effect (Piskač et al. 1990; Halouzka et al. 1990) and, combined with simultaneous infection with non-oncogenic Makek's disease viruses (MDV), resulted in a synergic suppressive effect on the lymphoid organs (Halouzka and Jurajda 1991c).

Non-pathogenic turkey herpesvirus THV-BIO-I, which is used in our ccuntry for vaccination against Marek's disease (MD) (Salaj et al. 1976) induces moderate transient cytolytic changes in the bursa of Fabricius and thymus of susceptible chickens when administered in high doses (Halouzka and Juraida 1992a). In the organs and tissues it causes the development of lymphoid cellulisates (Benda and Hložánek 1975; Witter et al. 1976).

The present study was designed to characterize the effects of PCB (Delor 103) on the pathogenesis of morphological changes in the organs of experimental chickens infected with THV-BIO-I contained in a commercial vaccine, MARVAK. 


\section{Materials and Methods}

The experimental birds were unsexed Brown Hisex chickens.

Turkey herpesvirus THV-BIO-I (HTV) in the form of MARVAK, a commercial vaccine, op. No. 30/620688 was administered to 1-day-old chicks intramuscularly in doses of approximately $10^{3}$ PFU in $0.2 \mathrm{ml}$ inoculum per bird. The chicks were fed a commercial feed mixture $\mathrm{K}$ and had water available ad libitum (Group 1).

Delor 103 (produced by Chemko Strážské), a technical preparation containing PCB, was dissolved in xylol and added to feed mixture $K$ by thorough mixing so that $1 \mathrm{~kg}$ of the feed mixture should contain $50 \mathrm{mg}$ PCB (Delor 103). Group 2 chickens were fed this contaminated feed mixture throughout the experiment.

Non-infected chickens fed non-contaminated feed mixture were used as controls (Group C).

At 1, 1, 3, 4 and 5 weeks after infection 5 chickens of each group were weighed and serologically examined for the presence of precipitating antibody to MD and precipitating MDV antigen by the method of double immunodiffusion in agar gel as described previously by Jurajda and $\mathrm{Ha}$ louzka (1991). The bursae of Fabricius and spleens were weighed. For histopathological examination tissue samples were taken from thymus, bursa of Fabricius, spleen, peripheral nerves (n. ischiadicus, pl. brachialis) and gonads. The tissue samples were fixed in $10 \%$ aqueous solution of formaldehyde, processed using the routine paraffin technique and stained with haematoxylin and eosin; the nerve samples were stained with luxol blue.

Cytolytic changes in the lymphoid organs were evaluated quantitatively in immunosuppression degrees (Isd) of 0 to 4, and immunosuppression (Is) index was assessed according to morphological criteria described in a previous report by Halouzka and Jurajda (1991a). Relative mass of the bursa of Fabricius and spleen and relative mass index were determined according to Lucio and Hitchner (1979). The results were evaluated in a TNS/GC (AK Slušovice) computer using Abstat programme at the $95 \%$ level of significance. The results of histological examination were presented graphically.

\section{Results}

Control chickens showed no signs of clinical disease and their organs exhibited no morphological changes.

In infected chickens fed non-contaminated feed mixture (Group 1) atrophy of the spleen was observed from the 4th week and atrophy of the bursa from the 5th week p. i.

Table 1

Body mass (in g), relative mass of the bursa of Fabricius and spleen of Brown Hisex chickens after infection with THV-BIO-I and administration of PCB (Delor 103)

\begin{tabular}{|c|c|c|c|c|c|c|c|c|c|c|}
\hline \multirow[b]{2}{*}{$\begin{array}{l}\text { Week } \\
\text { p. i. }\end{array}$} & \multirow[b]{2}{*}{ Group } & \multirow[b]{2}{*}{$\begin{array}{l}\text { No. of } \\
\text { chickens }\end{array}$} & \multirow{2}{*}{\multicolumn{2}{|c|}{$\begin{array}{lc} & \text { Body mass } \\
\overline{\mathbf{x}} & \text { SD }\end{array}$}} & \multicolumn{6}{|c|}{ Relative mass } \\
\hline & & & & & $\begin{array}{l}\text { Bursa } \\
\overline{\mathbf{x}}\end{array}$ & $\begin{array}{l}\text { Fabricius } \\
\text { SD }\end{array}$ & Index & $\overline{\mathbf{x}}$ & $\begin{array}{l}\text { Spleen } \\
\text { SD }\end{array}$ & Index \\
\hline $1 \mathrm{st}$ & $\begin{array}{l}\mathrm{C} \\
1 \\
2\end{array}$ & $\begin{array}{l}5 \\
5 \\
5\end{array}$ & $\begin{array}{l}60.2 \\
64.0 \\
57.6\end{array}$ & $\begin{array}{l}4.9 \\
6.6 \\
7.6\end{array}$ & $\begin{array}{l}0.202 \\
0.227 \\
0.194\end{array}$ & $\begin{array}{l}0.014 \\
0.047 \\
0.050\end{array}$ & $\begin{array}{l}1.000 \\
1.126 \\
0.960\end{array}$ & $\begin{array}{l}0.050 \\
0.078 \\
0.052\end{array}$ & $\begin{array}{l}0.011 \\
0.038 \\
0.015\end{array}$ & $\begin{array}{l}1.000 \\
1.564 \\
1.036\end{array}$ \\
\hline 2nd & $\begin{array}{l}C \\
1 \\
2\end{array}$ & $\begin{array}{l}5 \\
5 \\
5\end{array}$ & $\begin{array}{r}94.4 \\
97.0 \\
104.6\end{array}$ & $\begin{array}{r}8.8 \\
18.0 \\
19.3\end{array}$ & $\begin{array}{l}0.253 \\
0.360 \\
0.285\end{array}$ & $\begin{array}{l}0.064 \\
0.047 \\
0.026\end{array}$ & $\begin{array}{l}1.000 \\
1.422 \\
1.125\end{array}$ & $\begin{array}{l}0.087 \\
0.097 \\
0.080\end{array}$ & $\begin{array}{l}0.009 \\
0.014 \\
0.017\end{array}$ & $\begin{array}{l}1.000 \\
1.110 \\
0.922\end{array}$ \\
\hline $3 \mathrm{rd}$ & $\begin{array}{l}C \\
1 \\
2\end{array}$ & $\begin{array}{l}5 \\
5 \\
5\end{array}$ & $\begin{array}{l}145.8 \\
140.8 \\
153.2\end{array}$ & $\begin{array}{l}13.8 \\
11.8 \\
15.1\end{array}$ & $\begin{array}{l}0.434 \\
0.382 \\
0.330\end{array}$ & $\begin{array}{l}0.052 \\
0.121 \\
0.115\end{array}$ & $\begin{array}{l}1.000 \\
0.879 \\
0.761\end{array}$ & $\begin{array}{l}0.097 \\
0.123 \\
0.112\end{array}$ & $\begin{array}{l}0.011 \\
0.020 \\
0.032\end{array}$ & $\begin{array}{l}1.000 \\
1.264 \\
1.150\end{array}$ \\
\hline 4th & $\begin{array}{l}\mathrm{C} \\
1 \\
2\end{array}$ & $\begin{array}{l}5 \\
5 \\
5\end{array}$ & $\begin{array}{l}209.6 \\
191.4 \\
197.8\end{array}$ & $\begin{array}{l}26.3 \\
25.3 \\
12.7\end{array}$ & $\begin{array}{l}0.332 \\
0.371 \\
0.297\end{array}$ & $\begin{array}{l}0.092 \\
0.087 \\
0.071\end{array}$ & $\begin{array}{l}1.000 \\
1.119 \\
0.893\end{array}$ & $\begin{array}{l}0.265 \\
0.121 \\
0.112\end{array}$ & $\begin{array}{l}0.093 \\
0.027 \\
0.021\end{array}$ & $\begin{array}{l}1.000 \\
0.458 \\
0.423\end{array}$ \\
\hline 5th & $\begin{array}{l}C \\
1 \\
2\end{array}$ & $\begin{array}{l}5 \\
5 \\
5\end{array}$ & $\begin{array}{l}253.4 \\
250.6 \\
212.2\end{array}$ & $\begin{array}{l}15.6 \\
42.7 \\
36.4\end{array}$ & $\begin{array}{l}0.427 \\
0.472 \\
0.250\end{array}$ & $\begin{array}{l}0.061 \\
0.045 \\
0.050\end{array}$ & $\begin{array}{l}1.000 \\
1.105 \\
0.586\end{array}$ & $\begin{array}{l}0.289 \\
0.170 \\
0.117\end{array}$ & $\begin{array}{l}0.079 \\
0.016 \\
0.032\end{array}$ & $\begin{array}{l}1.000 \\
0.588 \\
0.403\end{array}$ \\
\hline
\end{tabular}

SD - standard deviation, $\overline{\mathbf{x}}-$ mean 


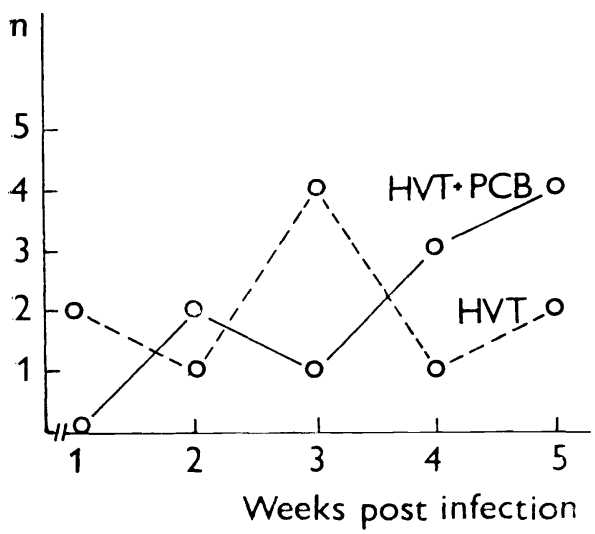

Fig. 1. Number of organs of Brown Hisex chickens showing lymphoid infiltrations after infection with HVT and administration of PCB.
Fig. 2. Dynamics of immunosuppressive changes in the central lymphoid organs of Brown Hisex chickens after infection with HVT and administration of PCB.
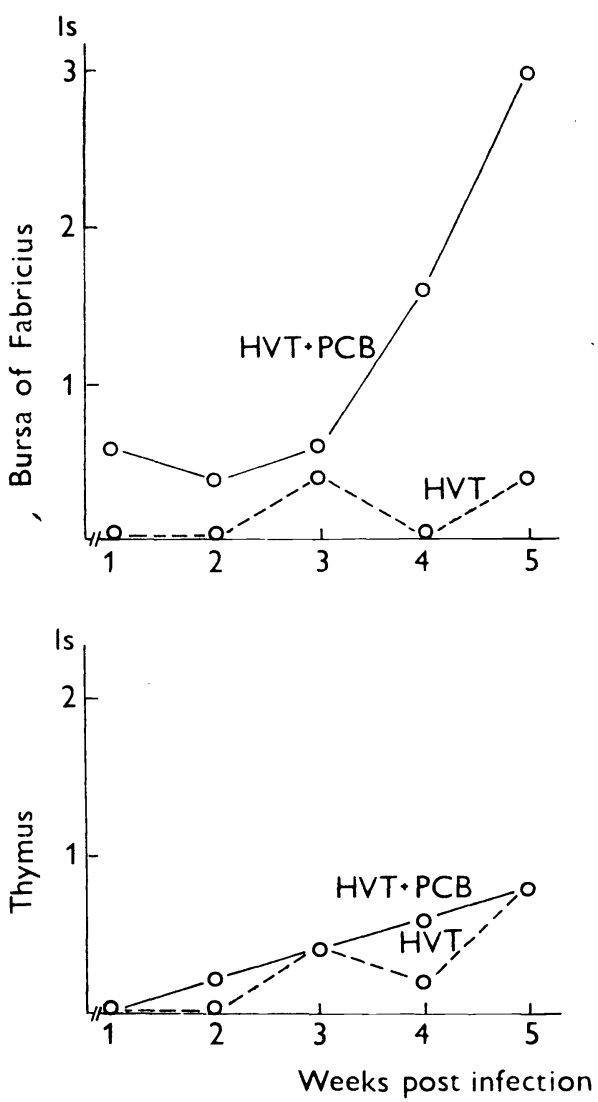

Infected chickens fed contaminated feed mixture (Group 2) exhibited apathy, moderate growth depression and feather ruffling from the 3rd week p. i. Post-mortem examination revealed yellow discolouration of the liver, increased volume of pericardial fluid, greyish foci in the myocardium and atrophy of the bursa and spleen from the 4 th week $p$. i.

Body mass and relative bursa and spleen mass are presented in Table 1.

Maternal and post-infection antibodies or antigen in the feathers were not found in any of the birds.

The incidence of lymphoid infiltrations in the organs of chickens is shown in Fig. 1. In Group 1 chickens perineural lymphoid cellulisate and analogous changes in the ovary were seen in one bird in the first week p. i. In the $2 n d$ p. $i$. week these changes were detected in the kidneys of one bird. In the 3rd p. i. week they were found in the kidneys of two birds, and in the ovary and skin in the form of discrete perifollicular lymphocyte aggregations in one bird. In the 4 th and 5 th p. i. weeks they were found only in the skin.

In Group 2 chickens interneuritic lymphocytic and heterophilic cellulisate was observed in two chickens in the 2 nd p. i. week. In the $3 \mathrm{rd} \mathrm{p}$. i. week a lymphoid focus was found in the ovary of one bird. In the 4th p. i. week it was found in the nerve accompanied by degeneration of neuraxons and in the intertubular 


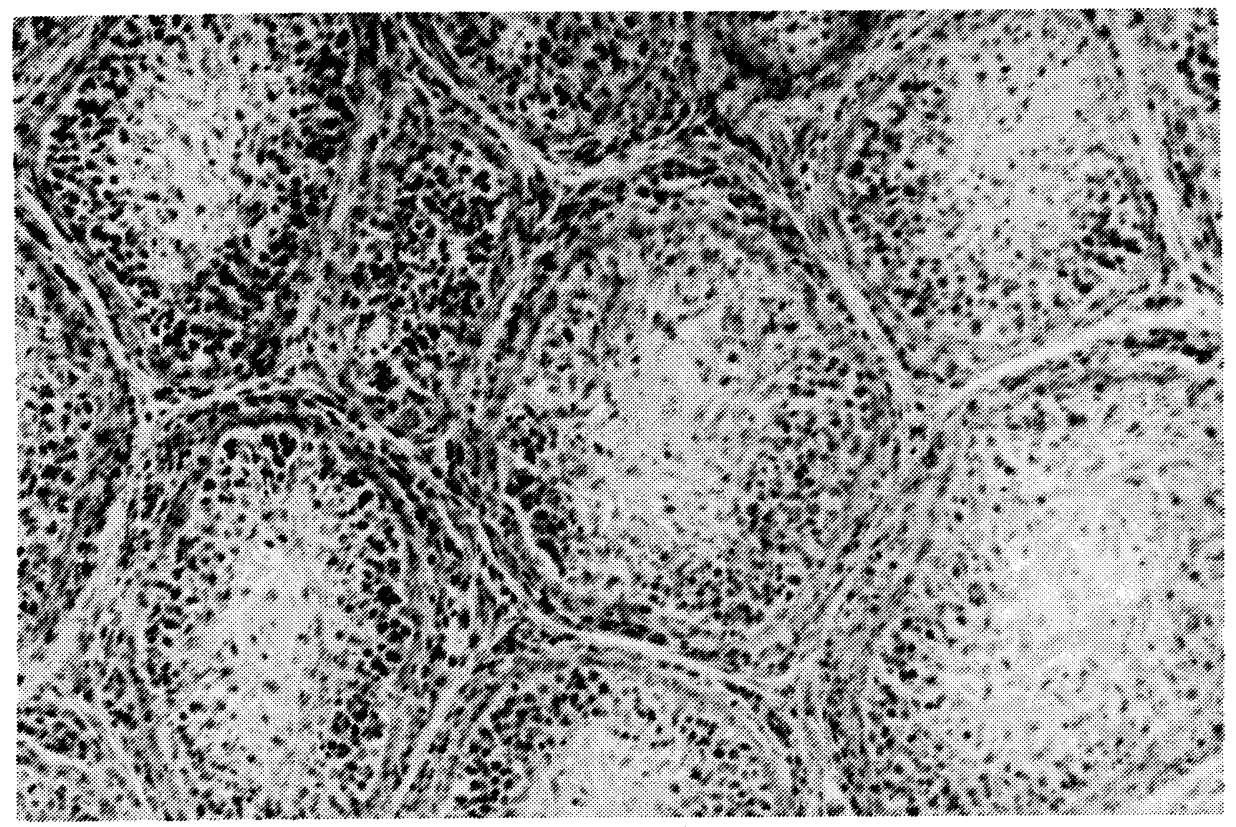

Fig. 3. Lymphocyte depletion of follicles in the bursa of Fabricius (Isd 3). He $\times 640$.

tissue of the testis in one bird. In the 5th p. i. week they were found in the skin of the ovary in two birds. In this group of chickens degenerative changes were found frequently in the feather medulla from the 4 th week p. $i$.

The dynamics of regressive changes in the bursa of Fabricius and thymus are shown in Fig. 2. In Group 1 chickens merely infected with HVT the cytolytic changes in the bursa and thymus were moderate and were evaluated mostly as Isd 1 to 2 . In the 5th p. i. week atrophy of the bursa was observed. Examination of the spleen in the 4 th p. i. week revealed hyperaemia, numerous nests of heterophilic granulocytes and minute neoplastic germinal centres. The periarteriolar walls and reticulum were atrophic. In the 5 th p. i. week reticular elements and erythrocytes in the spleen prevailed.

In Group 2 chickens cytolytic changes in the bursa and thymus were particularly marked. Up to the 3rd p. i. week they were evaluated mostly as Isd 2; from the 4th week Isd 3 and 4 prevailed. Intrafollicular and interfollicular fibrosis was detected in the bursa and total atrophy of the lobular cortex was observed in the thymus (Fig. 3 and 4). In the 4th week three chickens showed oedema of the bursa and atrophy of lymphoid tissue in the spleen.

\section{Discussion}

From the results reported here it appears that the high dose of vaccination virus THV-BIO-I did not affect the growth of Brown Hisex chickens and did not reduce their relative bursa mass, but it did reduce their relative spleen mass at the end of the experiment. The virus induced the development of lymphoid 
aggregations in the organs, which is in keeping with the relevant published data (Benda and Hložánek 1975; Witter et al. 1976). From the 4th p. i. week onwards HVT induced only discrete changes in the skin identical with those caused by MDV and suggestive of a weak capacity of the virus to spread to the external environment (Calnek et al. 1979).

Cytologic changes in the bursa of Fabricius and thymus of Group 1 chickens were moderate and their pathogenesis corresponded to the course of infection with avian herpesviruses (Calnek et al. 1979). Morphological signs of local cellular immunity were rare. From the 4 th p. i. week however, the virus caused a reduction in spleen mass with marked lymphocyte depletion. This result is rather surprising because it was not observed in our previous experiments with Brown Leghorn chickens infected with the same virus (Halouzka and Jurajda 1992a). A possible explanation may be different susceptibility of Brown Hisex and Brown Leghorn chickens and, in consequence, a different course of infection in the two genotypes.

In Group 2 chickens the effect of PCB (Delor 103) was manifested at the end of the experiment by decreases in body mass and relative bursa mass, which is in keeping with our previous findings (Halouzka and Jurajda $1992 \mathrm{~J}$ ). However, the decrease in relative spleen mass reported in the present study had not been found in our previous experiments with viruses exerting marked cytolytic effects on the lymphoid organs; in these previous experiments it was not observed even in chickens fed a PCB-contaminated feed mixture (Halouzka and Jurajda 1992b; Halouzka et al. 1990). The atrophy of the spleen seems therefore to have been caused by the high dose of HVT rather than by PCB.

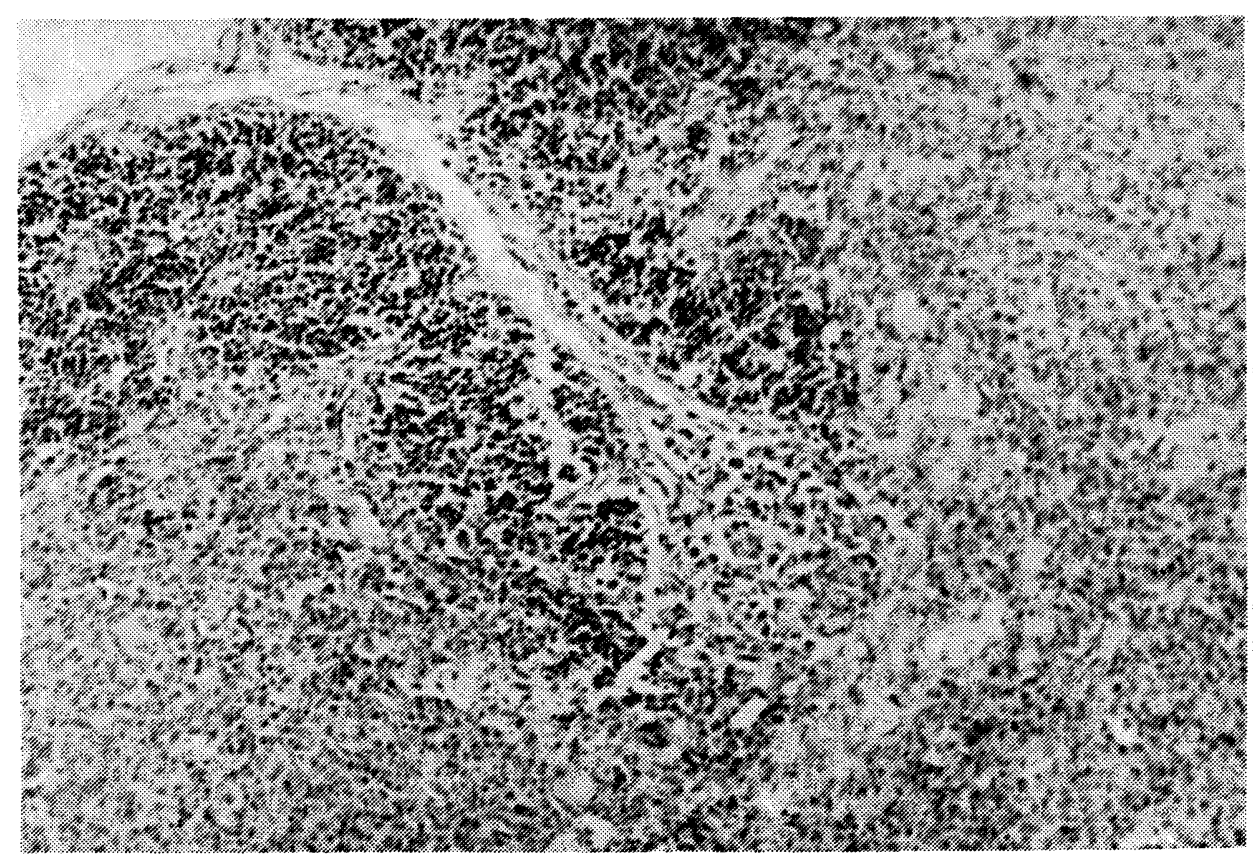

Fig. 4. Reduction of cellularity in the thymic lobular cortex (Isd 3). $\mathrm{HE} \times 640$. 
PCB (Delor 103) had no marked effects on either the incidence of lymphoid aggregations or their organ distribution. The degeneration of feather medulla responsible for the clinical condition observed in the present study was in keeping with our previous findings (Halouzka and Jurajda 1992b).

The most conspicuous cytolytic changes were observed in Group 2 chickens in the bursa of Fabricius in the 3rd p. i. week, resulting in atrophy and fibrosis of the organ at the end of the experiment. The dynamics of cytolytic changes in the present experiments with Brown Hisex chickens was different from the observations made by us previously in analogous experiments with Brown Leghorn chickens (Halouzka and Jurajda 1992b). In the latter the cytolytic changes in the bursa and thymus were at a higher level from the 1st week and their intensity rose moderately up to the 5th week. In the experiments with Brown Hisex chickens they were moderate from the 1st week and rose markedly in intensity only from the 3rd week. This seems to imply that a higher accumulation of PCB (Delor 103) in the tissues is necessary for development of its cytolytic -effects in Brown Hisex than in Brown Leghorn chickens.

Negative demonstration of post-infection antibody is associated apparently with slow replication of the virus and with immunosuppressive effects of PCB (Delor 103).

It can be concluded that polychlorinated biphenyls (Delor 103) reduced the body mass of the chickens and induced atrophy of the bursa of Fabricius at the end of the experiment. They did not affect the incidence of lymphoid aggregations in the organs. The atrophy of the spleen was caused apparently by the viral infection. In view of the cytolytic effects on the bursa of Fabricius it appears possible that PCB may eliminate post-vaccination immunity. Brown Hisex chickens used in the present study proved more resistant to the effects of PCB than Brown Leghorn chickens.

\section{Vliv polychlorovaných bifenylů na infekci kuřat virem THV-BIO-I}

$\mathrm{V}$ průběhu pětitýdenního pokusu jsme sledovali působení polychlorovaných bifenylů (PCB) na kuřata Hisex hnědý infikovaná vakcinačním krůtím herpetickým virem THV-BIO-I. Jedna skupina jednodenních kuřat byla infikována dávkou přibližně $10^{3} \mathrm{PFU}$ na kuře a krmena směsí $\mathrm{K}$, druhá skupina byla stejně infikována a krmena směsí $\mathrm{K}$ kontaminovanou $50 \mathrm{mg}$ PCB . $\mathrm{kg}^{-1}$ směsi. Kuřata neinfikovaná a krmena nekontaminovanou směsí byla kontrolní. Kuřata byla $\mathrm{v}$ týdenních intervalech sérologicky vyšetřována, vážena a lymfatické orgány, kủže, nervy a gonády byly histopatologicky vyšetřovány.

PCB způsobovaly snižení tělesné hmotnosti a poruchu růstu peři. Výskyt lymfoidních celulizátů $\mathrm{v}$ orgánech neovlivnily. Lymfatické orgány kuřat pouze infikovaných virem jevily pouze mírné cytologické změny. Na konci pokusu virus způsoboval atrofii sleziny a Fabriciovy burzy. Výraznější regresivní změny lymfatických orgánů jsme pozorovali od 3. týdne p. i. a aplikaci PCB, které mohou být př́činou vakcinačního selhání. Postinfekční protilátky jsme nezjistili u žádného kuřete. $V$ porovnání $s$ kuřaty Brown Leghorn se kư̌ata Hisex hnědý jevila odolnější proti působeni PCB. 


\section{Влияние полихлорированных бифенилов на инфекцию цыплят вирүсом THV/BIO-I}

В ходе пятинедельного эксперименты проводили исследования по воздействию полихлорированных бифенилов (РСB) на цыплятах Гисекс коричневыйж инфицированные вакцинирүющим индюшечным герпетическим вирусом THV-BIO-I. Одну группу цыплят суточного возраста инфицировали дозой около $10^{3} \mathrm{PFU}$ на цыпленка и кормили смесью. Вторую группу инфицировали одинаково и кормили смесью K, контаминированную 50 мг РСВ. $\mathrm{Kr}^{-1}$ смеси. Неинфицированные цыплята, кормленные неконтаминированной смесью стали контрольной группой. Проводили серологические исследования цыплят в недельных интервалах, взвешивали их, лимфатические органы, кожу, нервы и гонады гистопатологически исследовали.

РСВ вызывали понижение массы тела и нарушение роста перьев. На наличие лимфоидных целлюлизатов в органах они влияния не оказали. Лимфатические органы цыплят, инфицированных лишь вирусом, отличались только незначительными цитологическими изменениями. В конце эксперимента вирус вызывал атрофию селезенки и фабрициевой сумки. Более выразительные регрессивные изменения лимфатических органов наблюдали с 3 недели после инфекции и применения РСВ, которые могут быть причиной вакцинационной недостаточности. Послеинфекционные антителя не были выявлены нигде. По сравнению с цыплятами Браун Легхорн цыплята Гисекс коричневый отличались большей сопротивляемостью к воздействию РСВ.

\section{References}

BENDA, V.-I. HLOŽÁNEK: Effect of Large Doses of Turkey Herpes Virus on Antibody Response in Chickens. Folia biol. (Praha), 21, 1975: 184-188

CALNEK, B. W.-CARLISLE, J. C.-FABRICANT, J.-MURTHY, K. K. - SCHAT, K. A.: Comparative pathogenesis studies with oncogenic and nononcogenic Marek's disease viruses and turkey herpesvirus. Am. J. Vet. Res., 40, 1979: 541-548

HALOUZKA, R. - JURAJDA, V.: Morphological Expression of Immunosuppression in poultry. Acta vet. Brno, 60, 1991: $271-276$

HALOUZKA, R.-JURAJDA, V.: Patologické změny kuřat po infekci krůtím herpetickým virem THV-BIO-I. Veter. Med. (Praha), 1992a (in print)

HALOUZKA, R.-JURAJDA, V.: Vliv polychlorovaných bifenylů na infekci kuřat neonkogenní viry Markovy nemoci. Acta vet. Brno $1992 b$ (in print)

HALOUZKA, R.-RUPRICH, J. - PISKAČ, A.: Účinek polychlorovaných bifenylů na organismus kuřat: patologické změny orgánů po krátkodobém a dlouhodobém přijmu Deloru 103. Veter. Med. (Praha), 35, 1990: 303-312

JURAJDA, V.-HALOUZKA R.: Izolace a studium biologických vlastností neonkogenních kuřecích herpesvirů Markovy nemoci. 2. Charakterizace in vivo. Veter. Med. (Praha), 1991 (v tisku)

LUCIO, B.-HITCHNER, S. B.: Infectious bursal disease emulsified vaccine: effect upon neutralizing-antibody levels in the dam and subsequent protection of the progeny. Avian Dis., 23, 1979: $466-478$

PISKAČ, A.-RUPRICH, J.-HALOUZKA, B.: Účinek polychlorovaných bifenylů (PCB) na organismus kuřat: vliv krátkodobého př́imu vysokých dávek Deloru 103 na koncentraci thyroxinu, trijodthyroxinu, sodíku, draslíku a vápníku v krevním séru. Veter. Med. (Praha), 35, 1990: $237-246$

SALAJ, J.-ČASNOCHA, E.-ČERNIK, K.-ŽUFFA, A.-MALÁ, E. - LINDENSTEINOVÁ, M.-GUNIŚOVÁ, E.: MARVAK. Project report, Bioveta Nitra, 1976, 88p

WITTER, R. L.-SHARMA, J. M.-OFFENBECKER, L.: Turkey herpesvirus infection in chickens: Induction of lymphoproliferative lesions and characterization of vaccinal immunity agains Marek's disease. Avian Dis., 20, 1976: 676-692 